AT-TAWASSUTH: Jurnal Ekonomi Islam, Volume V No. 2

Juli - Desember 2020: 268 - 290

\title{
PERAN ISTRI DALAM MEMBANGUN EKONOMI KELUARGA MENURUT PERSPEKTIF HUKUM ISLAM DI KECAMATAN PANYABUNGAN KOTA
}

\author{
Dede Hafirman Said \\ STAIN Mandailing Natal \\ dedehafirmansaid@stain-madina.ac.id
}

\begin{abstract}
Pros and cons occur in society regarding the role of the wife and also as a career woman as well as the urgency of the wife to the impact of working women. People have started to open themselves up by allowing their wives to work as long as they do not violate their nature as a housewife with the aim of supporting the family's economy, although some are worried about the imbalance of these two roles in the family. This paper analyzes the efforts made by the wife who also works in the Panyabungan Kota District in building the family economy. This study used semistructured in-depth interviews with 5 respondents. The results showed that the working wife has tips on managing income in order to build the family economy. Islam does not prohibit a wife from having a career, but a wife does work that does not contradict her feminine nature and does not confine her rights at work and can maintain her honor and avoid harassment and behavior in accordance with Islamic law. A working wife must be able to solve problems of family and work conflicts that often conflict with each other.
\end{abstract}

Keywords: economy, family, Islam, wife, career woman

\begin{abstract}
Abstrak
Pro dan kontra terjadi di masyarakat tentang peran istri dan juga sebagai wanita karir serta urgensi istri hingga dampak yang ditimbulkan dari wanita yang bekerja. Masyarakat mulai membuka diri dengan diperbolehkan istri bekerja selama tidak melanggar fitrahnya sebagai ibu rumah tangga yang bertujuan menopang ekonomi keluarga walaupun sebagian merasa khawatir akan ketidakseimbangan terhadap kedua peran ini dalam keluarga. Tulisan ini menganalisis upaya yang dilakukan oleh istri yang juga bekerja pada Kecamatan Panyabungan Kota dalam membangun ekonomi keluarga. Penelitian ini menggunakan wawancara secara mendalam semi terstruktur terhadap 5 responden. Hasil penelitian menunjukkan bahwa istri yang bekerja memiliki kiat mengelola pendapatan dalam rangka membangun ekonomi keluarga. Islam tidak melarang istri untuk berkarir, namun istri melakukan pekerjaan yang tidak bertentangan dengan kodrat kewanitaannya dan tidak mengungkung haknya di dalam pekerjaan serta dapat menjaga kehormatan dirinya dan menghindarkan diri dari pelecehan, serta perilaku sesuai dengan syariat Islam. Seorang istri yang bekerja harus dapat mengatasi persoalan konflik keluarga dan pekerjaan yang seringkali bertentangan satu sama lain.
\end{abstract}

Kata Kunci: ekonomi, keluarga, Islam, istri, wanita karir

\section{Pendahuluan}


Era globalisasi yang didukung perkembangan ilmu dan teknologi yang pesat saat ini, berimplilkasi semakin kaburnya batasan jenis pekerjaan bagi pria maupun istri. ${ }^{1}$ Keadaan ini juga mendorong istri untuk ikut berperan serta dalam mengekspresikan kemampuan intelektualitas sekaligus juga dapat merupakan sarana untuk membantu perekonomian keluarga dengan bekerja di sektor publik. ${ }^{2}$ Dulu peran istri identik dengan pekerjaan di rumah tangga, seperti melayani suami, mendidik anak, dan mengurus pekerjaan di dalam rumah. Kini, peran istri mengalami banyak perubahan. Istri tidak lagi puas dengan pekerjaan di rumah tangga, sehingga banyak sekali Istriyang memilih untuk terjun di dunia karir.

Survei yang dilakukan oleh Grant Thornton menunjukkan bertambahnya posisi senior pada perusahaan di dunia yang diisi oleh kaum Istri. Secara global, Eropa Timur menjadi kawasan yang memberikan kesempatan kepada 35 persen kaum Istrimemimpin dalam sebuah perusahaan. Indeks gender equality Indonesia di ASEAN dilihat dari sisi partisipasi pasar tenaga kerja, memperlihatkan pada sektor informal ada $30 \%$ kaum pria, sedang kaum istri $70 \%$.

Keterlibatan istri di sektor produksi tidak berdampak pada perlakuan yang sama untuk suami dalam mengurus urusan domestik keluarga dan anak. Meskipun istri yang bekerja di ruang publik, mereka masih mempunyai tugas-tugas domestik. Pembagian waktu antara pekerjaan dan peran sebagai istrimenjadikan peran dan beban istri pekerja di ruang publik lebih berat karena menjadikan mereka mempunyai peran ganda, istri sebagai pencari nafkah sekaligus penanggung jawab urusan rumah tangga.

Persoalannya, ketika istri memilih untuk menjalani sebuah pekerjaan (karir), terutama bagi istriyang sudah menikah, ia akan memiliki peran ganda yang dapat menimbulkan persoalan baru yang lebih kompleks dan rumit. Tugas istrisebagai wanita karir menjadi lebih banyak. Disamping tuntutan untuk memenuhi kewajibannya di dalam rumah tangga, ia juga memiliki beban untuk menyelesaikan tugas dan tanggung jawabnya di dalam pekerjaan.

Peran ganda bagi istribukanlah situasi yang mudah untuk diselesaikan. Kedua peran tersebut menuntut kinerja yang sama baiknya. Apabila istrilebih 
270 AT-TAWASSUTH: Jurnal Ekonomi Islam, Volume V No. 2

Juli - Desember 2020: 268 - 290

memprioritaskan pekerjaan, maka ia dapat mengorbankan banyak hal untuk keluarganya. Sebaliknya apabila istrilebih memprioritaskan keluarga, maka ia cenderung akan menurunkan kinerjanya di dalam pekerjaan. Inilah yang disebut konflik keluarga dan pekerjaan.

Fenomena istri dengan peran ganda ini telah menjadi perhatian para peneliti. Hasil penelitian yang ada telah menunjukkan adanya perubahan cara pandang masyarakat terhadap peran dan posisi istri di tengah masyarakat, motif istri bekerja di luar rumah, keuntungan bagi keluarga, maupun problem yang muncul dari perempuan yang bekerja di ruang publik karena berubahnya fungsi ibu, kurangnya waktu untuk keluarga dan bermasyarakat.

Inilah posisi dilematis yang dialami oleh seorang istri dalam kehidupannya khususnya di Kecamatan Panyabungan Kota. Faktanya, banyak istri yang tidak dapat menyeimbangkan peran tersebut secara proporsional. Seringkali ada ketidakseimbangan antara pekerjaan di dalam rumah tangga dan pekerjaan, sehingga berdampak buruk pada kehidupannya di dalam rumah tangga dan di dalam pekerjaan. Tulisan ini menjelaskan urgensi istri (wanita karir) dalam konteks sosial dan ekonomi, peran istri sebagai ibu rumah tangga dan wanita karir, peran ganda istri (wanita karir), konflik keluarga dan karir dan tinjauan hukum Islam terhadap istri (wanita karir). Sehingga hal ini menarik untuk diteliti khususnya di Kecamatan Panyabungan Kota bagaimana peran ganda istri dan juga sebagai wanita yang bekerja dalam mendukung dan menopang ekonomi keluarga.

\section{Kajian Teori}

Istilah istri karir dan istri pekerja sesungguhnya sama-sama berorientasi untuk menghasilkan uang. Istri karir adalah istri yang cenderung sudah lebih mapan status ekonominya dan lebih memprioritaskan status sosial atau jabatannya, sedangkan istri bekerja, motivasi utamanya adalah untuk memenuhi dan mencukupi kebutuhan ekonomi (nafkah) keluarga. Eksistensi istri tidak hanya berdampak terhadap diri dan keluarga, tetapi juga sangat berpengaruh terhadap masyarakat, bangsa dan negara. Bahkan kemajuan atau kehancuran negeri tergantung pada perempuan. Perempuan 
yang terdidik dengan baik akan melahirkan generasi yang baik dan memakmurkan negeri. ${ }^{3}$

Kesetaraan peran, kedudukan dan tanggung jawab antara laki-laki dan perempuan atau lebih popular dengan istilah gender, merupakan isu global yang melintasi batas negara, agama dan budaya. Tidak terkecuali di Indonesia dengan penduduk mayoritas muslim, isu gender, wacana, konsep, aktualisasi beserta kontroversinya masih terus berkembang. Budaya dan agama seringkali dianggap sebagai penghambat kesetaraan gender. Begitu pula konsep-konsep yang dianut dan dipahami dalam Islam dianggap oleh sebagian orang bahkan oleh para aktivis Islam sendiri dan kaum feminis sebagai konsep yang tidak sejalan dengan semangat gender. Salah satu dasar yang sering diangkat untuk menjustifikasi pantangan tersebut adalah kaum pria adalah qawamuna atas kaum perempuan. Qawamuna dalam arti harfiahnya adalah sebagai pemimpin, dan dianggap menutup ruang bagi kaum perempuan untuk mencapai kesetaraan dalam peran sosialnya dengan laki-laki. ${ }^{4}$

Demikian pula halnya dengan peran perempuan dalam menyampaikan syiar Islam, selama ini peran laki-laki dalam menyampaikan syiar Islam atau berdakwah di mesjid-mesjid atau acara-acara keagamaan lebih diprioritaskan dibandingkan dengan kaum perempuan yang ingin tampil melakukan dakwah Islam dan bahkan dikatakan bahwa perempuan yang berdakwah didepan umum suaranya merupakan aurat yang harus ditutup atau tidak diperdengarkan. ${ }^{5}$

Peran perempuan dalam konteks berbangsa dan bernegara tidak hanya terlihat pada masyarakat perkotaan, tetapi juga ada pada masyarakat pedesaan, dan bahkan penduduk pedalaman yang notabene berlatar belakang pendidikan rendah, dan menganut budaya patriarki. Namun demikian, kurang atau tidak tercukupinya kebutuhan ekonomi sangat memantik setiap perempuan untuk bersikap responsif, yakni berpartisipasi dalam memenuhi kebutuhan dasar. Upaya-upaya ibu rumah tangga dalam membangun kesejahteraan keluarga sudah banyak dilakukan sebagai wujud kreativitas istri dalam meningkatkan kesejahteraan keluarga. Gerakan feminisme melalui institusi merupakan salah satu wujud upaya perempuan dalam 
memerangi kemiskinan dan memajukan kesejahteraan keluarga, ketika pendapatan suami kurang atau bahkan tidak mendapat nafkah ekonomi dari suami.

Istri bekerja dapat dibedakan menjadi dua kelompok. Pertama, mereka yang bekerja untuk penyaluran hobi, pengembangan bakat dan meningkatkan karir, yang lebih populer dengan istilah istri (wanita karir). Golongan ini selalu menghubungkan lapangan pekerjaan dengan bakat mereka serta kesenangan, sedang perumusan material menjadi nomor dua bagi mereka. Kedua, Mereka yang bekerja untuk memenuhi kebutuhan hidup atau karena tekanan ekonomi, dengan kata lain untuk perbaikan sosial. Kelompok ini lebih dikenal dengan Istri pekerja. Golongan ini lebih banyak menghubungkan pekerjaan dengan pemenuhan kebutuhan material dengan penghasilan yang mereka terima. Dalam kaitannya dengan peranan dalam keluarga, istri pekerja atau istri karir mempunyai peran ganda. Pada satu sisi, istri pekerja tetap dengan tugas domistiknya sebagai penanggung jawab utama urusan domestik rumah tangga, pada sisi yang lain, mereka juga mempunyai beban untuk mencari nafkah keluarga. Peran domestik rumah tangga meliputi peran sebagai istri dan peran sebagai ibu yang berperan untuk mengurus dan mendidik anak-anaknya. ${ }^{6}$

Selain peran domestik, istri pekerja juga mempunyai peran publik. Peran publik istri ini merupakan pergeseran peran istri dari peran domestik ke publik, dimana hal ini merupakan tanda penting dari perkembangan realitas sosial, ekonomi, dan politik istri. Istri telah menjadi faktor penting dalam ekonomi rumah tangga. Namun perkembangan peran publik istri ini juga terlepas dari kendala baik yang dihadapi dalam keluarga akibat keterlibatan di luar rumah ataupun dalam dunia kerja itu sendiri. ${ }^{7}$

Struktur peran dapat dibedakan menjadi dua, yaitu peran formal dan peran informal. Peran formal merupakan peran yang nampak jelas di mana sejumlah perilaku yang bersifat homogen. Peran formal yang standar terdapat di dalam keluarga. Peran dasar yang membentuk posisi sosial sebagai suami-ayah dan istri-ibu adalah peran sebagai provider (penyedia), pengatur rumah tangga, memberikan perawatan sosialisasi anak. Sedangkan peran informal atau disebut peran pertutup, yaitu suatu peran yang bersifat implisit (emosional) biasanya tidak tampak ke 
permukaan dan dimainkan hanya untuk memenuhi kebutuhan emosional individu dan untuk menjaga keseimbangan di dalam keluarga. Peran-peran informal mempunyai tuntutan yang berbeda, tidak terlalu dan didasarkan pada atribut-atribut kepribadian anggota keluarga individual. Pelaksanaan peran-peran informal yang efektif dapat mempermudah pelaksanaan peran-peran formal. ${ }^{8}$

Al-Qur'an mengakui adanya perbedaan jenis kelamin (biologis) antara lakilaki dan perempuan. ${ }^{9}$ Tetapi perbedaan ini tidak berarti ketidaksetaraan dalam status jenis kelamin. Sebagai kitab yang progresif, egaliter dan humanistik, al-Qur'an memandang sejajar antara laki-laki dan perempuan. Hal ini dapat dilihat dalam penggambaran al-Qur'an tentang asal pencipta laki-laki dan perempuan dari jenis yang sama. ${ }^{10}$ Oleh karena itu mustahil dari jenis yang satu lahir makhluk yang berbeda (tidak sejajar). Dengan demikian laki- laki dan perempuan memiliki status yang sama (sejajar) dan tidak ada yang lebih unggul satu atas lainnya.

Pada Al-Qur'an Surat Al-Isra' ayat 70 yang artinya: "Dan sesungguhnya telah kami muliakan anak-anak Adam, Kami angkut mereka di daratan dan di lautan. ${ }^{11}$ Kami beri mereka rezki dari yang baik-baik dan Kami lebihkan mereka dengan kelebihan yang sempurna atas kebanyakan makhluk yang telah Kami ciptakan."12 Ayat ini menjelaskan bahwa al-Qur'an telah mengangkat derajat perempuan menuju singgasana kesetaraan dengan kaum laki-laki. Alasannya, pertama sebagaimana ditunjukkan oleh ayat diatas, al-Qur'an memberikan tempat yang sangat terhormat kepada seluruh manusia laki-laki maupun perempuan. Kedua, sebagai norma, alQur'an membela prinsip-prinsip kesetaraan dalam status dan jenis kelamin. Fungsifungsi biologis harus dibedakan dari fungsi-fungsi sosial.

Dengan begitu, posisi kaum laki-laki dianggap sebagai raja di dalam keluarga, masyarakat, organisasi, serta di tempat mereka bekerja, dan perempuan sebagai batur (pembantu), tetap kukuh dan tak tergoyahkan. ${ }^{13}$ Dalam agama Islam perempuan dibolehkan bekerja selama pekerjaannya itu tidak menyampingkan keluarga, telah dijelaskan dalam kitab Al-Qur'an (al-rijaalu qawwamuna al anisa'). Dalam Alqur'an dijelaskan bahwa kaum laki-laki memperoleh bagian dari hasil usaha mereka dan kaum perempuan memperoleh pula bagian dari usaha mereka. ${ }^{14}$ Al-Qur'an 
menegaskan bahwa laki- laki dan perempuan sama-sama berhak memperoleh pekerjaan yang layak, sehingga mereka juga memperoleh upah kerja yang layak pula.

Wanita yang berkarir memiliki peran ganda, yaitu peran di dalam rumah tangga dan keluarga sebagai kodrat yang melekat pada diri seorang wanita, serta peran di dalam suatu pekerjaan di luar rumah. Dengan demikian ada beberapa persyaratan yang harus dipenuhi oleh seorang wanita yang ingin berkarir. Memiliki kesiapan mental istri (wanita karir) harus memiliki wawasan tentang bidang yang digelutinya dan memiliki keberinan memikul tanggung jawab sehingga tidak bergantung pada orang lain. Kesiapan jasmani istri (wanita karir) harus sehat secara fisik dan memilki stamina untuk menekuni bidang pekerjaan tertentu. Kesiapan sosial, di mana seorang wanita karir harus memiliki kemampunan untuk Mengembangkan keharmonisan hubungan antara karir dan kehiatan rumah tangga. menumbuhkan saling pengertian dengan keluarga dekat dan tetangga, mengontrol pergaulan yang luas dengan cara menjaga martabat diri sehingga terhindar dari fitnah dan gosip, dan beradaptasi dengan lingkungan terkait. Memiliki kemampuan untuk selalu meningkatkan prestasi kerja demi kelangsungan karir di masa depan. Menggunakan peluang dan kesempatan yang baik.Mempunyai pendamping yang mendukung dengan gagasan baru.

\section{Metode Penelitian}

Jenis penelitian ini adalah penelitian yang menggunakan pendekatan kualitatif deskriptif. Sumber data diperoleh menggunakan metode wawancara secara mendalam secara semi tertruktur terhadap 5 (lima) responden di Kecamatan Panyabungan Kota. Para responden tersebut merupakan istri dan juga wanita karir yang bekerja di salah satu instansi pemerintahan di Kecamatan Panyabungan Kota Kabupaten Mandailing Natal. Setelah itu dilakukan analisis terkait upaya-upaya dalam membangun kesejahteraan ekonomi keluarga. Untuk memperkaya pembahasan, penelitian juga melakukan kajian terhadap buku-buku, artikel, dan undang-undang yang terkait dengan pokok penelitian, sehingga pada akhirnya dijadikan langkah dalam mengambil kesimpulan sebagai jawaban dari rumusan masalah yang ada.

\section{Hasil Dan Pembahasan}

\section{Urgensi Istri Yang Bekerja pada Kecamatan Panyabungan Kota}


Keterlibatan seorang istri dalam pekerjaan saat ini sudah tidak dapat terelakkan. Terlepas dari pro dan kontra yang terjadi, kenyataanya banyak posisi dalam bidang peker- jaan atau profesi yang membutuhkan tenaga seorang istri. Di sisi lain, para istri dewasa ini sudah siap mengisi posisi tersebut dengan berbekal kemampuan akademis, keahlian, dan pengalamannya. Motivasi istri untuk berkecimpung di dunia karir tidak hanya disebabkan oleh faktor-faktor ekonomi, melainkan juga karena faktor individu yang ditimbulkan oleh keinginan untuk mengembangkan diri dan berperan dalam lingkungan sosial. Keinginan individu inilah yang membuat banyak istri mulai merasa tidak puas dengan hanya menjadi ibu rumah tangga yang hanya beperan di dalam rumah. Istri tidak lagi merasa menjadi orang nomor dua dibawah laki-laki. Terbukti, semakin banyak istri yang melanjutkan pendidikan hingga ke perguruan tinggi. Ketika lulus, istri siap berkarir sesuai dengan minat, bakat dan bidang keahliannya.

Terjunnya istri dalam dunia karir ternyata banyak memberikan pengaruh terhadap segala aspek kehidupan, baik kehidupan pribadi dan keluarga, maupun kehidupan masyarakat sekitarnya. Ada beberapa urgensi dengan adanya istri karir, yaitu:

1) Sisi ekonomi.

Keberadaan istri karir sangat penting bagi di dalam keluarga. istri karir dapat membantu dan meringankan beban suami dalam memenuhi kebutuhan keluarga. Tekanan inflasi dan kebutuhan manusia yang semakin kompleks dan bervariasi saat ini telah membuat banyak istri untuk membantu suaminya dalam mencari nafkah dalam upaya memenuhi kebutuhannya tersebut.

2) Sisi psikologis.

Istri yang tidak berkarir biasanya dekat dengan kegiatan-kegiatan yang tidak bermanfaat seperti berkhayal, melamun, dan memikirkan hal-hal yang tidak dirasakannya. Jika istri yang menganggur tidak dapat mengisi waktu kosongnya dengan hal-hal yang positif, maka tidak jarang mereka akan banyak menghayal dan pada jangka panjang dapat mengganggu jiwanya. Sedangkan istri berkarir kemungkinan besar akan terhindar dari hal-hal tersebut, sebab ia akan disibukkan 
dengan sejumlah tanggung jawab dalam pekerjaannya. Dengan kata lain, karir akan mendorong istri untuk banyak berpikir positif dan produktif.

3) Sisi sosial dan pembangunan.

Dalam memajukan dan mensejahterakan masyarakat dan bangsa diperlukan partisipasi serta keikutsertaan kaum istri, karena dengan segala potensinya istri mampu dalam hal ini. Bahkan ada sebagian pekerjaan yang tidak bisa dilaksanakan oleh laki-laki dapat berhasil ditangani oleh istri, baik karena keahliannya atau karena bakatnya. Faktanya banyak sekali istri yang telah menjadi pemimpin dalam berbagai perusahaan dan lembaga publik dan menunjukkan prestasi yang sangat baik.

\section{Peran Istri sebagai Ibu Rumah Tangga dan Wanita Karir}

Peribahasa berbahasa Arab yaitu, waktu adalah pedang. Jika para istri yang berkarir menyia-nyiakan waktu, maka mereka akan mengalami kerugian yang sangat besar. Demikianlah peribahasa yang menggambarkan bagaimana posisi waktu dalam kehidupan manusia. Dari peribahasa tersebut dapat ditarik kesimpulan bahwa setidaknya, bagi mereka yang hidup dengan mata pencaharian sebagai pedagang, waktu tidak dapat disia-siakan. Hal berbeda terjadi jika posisi para istri karir juga sebagai ibu rumah tangga (istri). Kemungkinan kerugian dapat timbul dari posisi keluarga (pembinaan anak) dan kemungkinan lain timbul dari posisi pekerjaan (kerugian). Keterpaksaan melakukan sesuatu pekerjaan yang dilakukan manusia merupakan hasil dari cara berfikir mereka.

Kehidupan ini dapat tergambarkan jika kita dapat bertahan hidup. Perkembangan akan semua yang menjadi kebutuhan kita seperti makanan, minuman, pakaian, materi kepuasan seperti rumah, motor, dan mobil adalah sesuatu yang diperlukan manusia secara tidak langsung. Keinginan akan pemenuhan kepuasan tersebut merupakan sumber dari seseorang melakukan sesuatu pekerjaan. Menjalani kodrat dari Tuhan yang akan dialami oleh semua orang, dan menjadi tugas sebagai seorang manusia yang hidup di dunia. Memahami sutau keadaan keluarga itulah yang harus dimengerti dari peran sang suami dan peran istri. Membangun keluarga harus 
sesuai dengan komitmen berupa janji suci yang diucapkan sang suami kepada sang istriketika menjalani pernikahan.

Demikian halnya dalam ranah keluarga, peran laki-laki akan bertindak sebagai ayah, ataupun kepala keluarga dengan alasan untuk kepentingannya dan dia harus tunduk kepada jenis kelamin yang lebih unggul. Peran perempuan dibatasi hanya di wilayah dapur, sumur dan kasur, atau biasa disebut dengan istilah 3M (macak, manak, dan masak). Pembagian peran tersebut jika diterapkan secara ketat dan kaku, dan mempertahankan tradisi yang berlaku, bahkan tidak sesuai dengan aturan dalam rumah tangga pada zaman sekarang. Peran suami dan istri itu tidak terpaku dalam tradisi yang ada, tetapi justru jauh sekali dari tradisi dan kebudayaan yang ada. Seperti seorang istri juga harus bisa mencari nafkah dan bahkan banyak sekali yang memerankan seperti itu, istri tidak hanya patuh dan menjalankan kodratnya, tetapi juga bisa mencari nafkah atau menjalankan karir/pekerjaan mereka, seperti dimulai dari hobi, kesukaan, perkumpulan/organisasi, dan lain sebagainya. Karena kodrat seorang istri, selain menjalani perannya, banyak sekali perkumpulan ibu arisan rumah tangga, dan perkumpulan istri karir yang lebih mengedepankan tampilan, fashion, dan pergaulan. $^{15}$

Secara kodrat istri tergantung pada suami, sementara peran suami mencari nafkah lebih memungkinkan laki-laki untuk memiliki akses sumber daya sosial dan politik dan tentunya penguasaan atas sumber daya ekonomi. Akan lebih tragis lagi apabila terjadi musibah, suami di-PHK atau keluar dari pekerjaannya, akan terjadi ketidakstabilan atau ketimpangan keluarga. Bahkan ada anggapan bahwa dalam pandangan fikih, Islam tidak mempunyai gambaran tentang seorang perempuan yang bekerja. ${ }^{16}$ Sementara itu, apa yang disampaikan oleh salah satu dari istri, bahwasanya pendapatan dari suami tidak mencukupi kebutuhan keluarga. Semua itu akan dianggap cukup, apabila disesuaikan dengan kebutuhan sebenarnya. Dalam pembagian pendapatan suami terkadang juga muncul masalah ketika suami tidak memberikan sepenuhnya kepada istri. Meskipun demikian, istri harus bisa menerima pemberian sekecil apapun itu dari suami, pasti akan dicukupkan demi kesejahteraan keluarga. $^{17}$ 
Mungkin ada sebagian istri yang tidak bisa menerima hasil dari pendapatan suami yang terlalu kecil, tetapi ada pula yang menerimanya dengan ikhlas. Sebagai seorang ibu rumah tangga, seorang istri seharusnya tidak hanya bergantung pada pendapatan suami. Dengan adanya himpitan ekonomi tersebut, ibu rumah tangga harus berjuang untuk menyejahterakan keluarga dengan berbagai cara. Misalnya, mulai usaha kecil-kecilan seperti membuka warung makan karena rumahnya dekat kampus. Kesejahteraan keluarga tidak harus ditandai dengan besarnya penghasilan suami, tetapi tergantung bagaimana istri mengelola pendapatan tersebut untuk kesejahteraan keluarga. ${ }^{18}$ Sementara itu dalam pendapatan suami, istri pun akan menggunakan cara atau trik tersendiri dalam mengatur keuangan. Keadaan seperti itulah, sebagai isiti pun harus mengerti apa yang harus dia lakukan, dan setiap permasalahan yang muncul mengenai keuangan pasti yang akan mengatasi itu berawal dari istri. Setelah itu suami akan mengerti dan memberi masukan dan kritikan untuk perbaikan kedepannya. ${ }^{19}$

Adapun secara yuridis, Indonesia juga telah mengatur peran istri. Pengaturan tentang peran istri ini sepertinya lebih fokus pada peranan istri di wilayah domestik. Ini dapat dilihat dari aturan yuridis tentang peran istri dalam rumah tangga dalam bab VI Pasal 30 Undang-Undang Perkawinan. Secara eksplisit, pasal tersebut menyatakan bahwa suami istri memikul kewajiban yang luhur untuk menegakkan rumah tangga yang menjadi sendi dasar dari susunan masyarakat. Lebih dari itu, pasal Pasal 31 ayat 1 (satu) dan 2 (dua) menegaskan kembali kedudukan seimbang suami isteri dalam keluarga. Pasal 31 ayat 1 (satu) menyatakan bahwa kedudukan suami dan isteri adalah seimbang dalam hak dan kewajiban. Sedangkan pasal 33 ayat 2 (dua) menjelaskan bahwa rumah kediaman atau tempat tinggal ditentukan bersama oleh suami dan isteri.

\section{Peran Ganda Istri Karir: Konflik Keluarga dan Karir}

Peran ganda merupakan beberapa peran yang dimiliki oleh satu orang dalam menjalankan tugas dan kewajibannya. Dalam konteks istri yang berkarir, peran ganda meliputi peran di dalam rumah tangga dan peran di luar rumah (karir). Ketika seorang wanita terutama yang sudah menikah memilih untuk berkarir, maka ia akan 
dihadapkan pada dua peran yang sama pentingnya, yaitu peran di dalam keluarga dan peran di dalam pekerjaan (karir). Peran istri sebagai istri dan ibu tidaklah mudah. Meskipun pekerjaan mengurus rumah tangga, melayani suami, dan merawat serta mendidik anak bukanlah kegiatan produktif secara ekonomi, namun pekerjaan tersebut sangat penting artinya bagi kehidupan anggota keluarga.

Menjalankan dua peran sekaligus secara tidak langsung memberikan dampak baik bagi istri itu sendiri maupun bagi lingkungan keluarganya. Istri dengan peran ganda dituntut untuk berhasil dalam dua peran yang berbeda. Di rumah mereka dituntut untuk berperan subordinat dengan kedudukan peran di bawah peran suami dalam menunjang kebutuhan keluarga dengan mengurus suami dan anak namun di tempat kerja mereka dituntut untuk mampu bersikap mandiri dan dominan. Kondisi tersebut seringkali menjadi dilema bagi seorang istri yang berkarir. Disatu sisi, ia harus memiliki kesempatan untuk menghasilkan kinerja terbaik di dalam pekerjaannya, namun disisi lain ia juga harus memiliki waktu untuk melayani suami, mendidik anak-anaknya, dan mengurus keperluan- keperluan rumah tangga lainnya.

Konflik keluarga dan karir merupakan salah satu bentuk dari inter-role conflict, yaitu tekanan atau ketidakseimbangan peran antara peran di dalam pekerjaan dan peran di dalam keluarga. Tuntutan keluarga berhubungan dengan waktu yang dibutuhkan untuk menangani pekerjaan atau tanggung jawab di dalam rumah tangga, menjaga anak, atau mengurus orang tua. Sedangkan tuntutan di dalam karir (pekerjaan) berkaitan dengan tekanan yang berasal dari beban kerja yang berlebihan dan waktu, seperti pekerjaan yang harus diselesaikan terburu-buru dan mengejar deadline.

Setidaknya ada tiga konflik dari peran ganda istri yang dapat terjadi antara lain; persoalan pengasuhan anak, pekerjaan rumah tangga, dan minimnya interaksi dalam rumah tangga.

\section{1) Pengasuhan Anak}

Istri yang menyandang status seorang ibu memiliki tanggung jawab yang sangat besar dalam mengasuh anak-anaknya. Peran ibu setidaknya meliputi pengasuhan anak, menjaga kesehatan anak, dan mendidik anak agar mereka tumbuh 
dan berkembang dengan baik secara fisik dan mental. Perhatian dan kasih sayang ibu juga sangat penting untuk menjaga kebahagiaan anak-anak. Ibu yang memiliki waktu yang banyak untuk anak akan dapat dengan mudah mengontrol aktivitas anak dan menyelesaikan dengan cepat berbagai persoalan yang dialami anak. Ketika seorang ibu memilih untuk berkarir, maka waktu yang dimiliki ibu dalam mengurus dan mendidik anak akan berkurang, dan dalam ban- yak kasus peran ibu kerap digantikan oleh orang lain. Sebagian ibu yang berkarir memilih untuk mencari pembantu rumah tangga untuk mengasuh anaknya, ada juga yang menitipkan anaknya di tempat penitipan anak. Dalam kasus ini, banyak sekali anak-anak yang kurang bahagia berada dirumah karena merasa kurang mendapat perhatian dan kasih sayang seorang ibu.

\section{2) Pekerjaan Rumah Tangga}

Selain menjadi ibu, istri sering kali diberikan tanggung jawab atas berbagai pekerjaan di dalam rumah, seperti membersihkan rumah, mencuci baju, menyetrika baju, dan menyiapkan makanan untuk suami. Pekerjaan ini membutuhkan waktu dan tenaga yang ekstra bagi seorang istri. Sebagian pekerjaan-pekerjaan tersebut mungkin bisa digantikan oleh orang lain, misalnya pembantu, namun melayani suami adalah kewajiban istri yang tidak dapat digantikan oleh siapapun. Peran istri dalam hal ini adalah meluangkan waktu yang cukup untuk melayani suami dan memberikan dukungan dalam pekerjaannya, dan sebagainya.

\section{3) Interaksi Dalam Rumah Tangga}

Komunikasi dan interaksi adalah sarana untuk mengutarakan kebutuhan, keinginan, keluhan atau persoalan-persoalan yang sedang dihadapi oleh anggota keluarga. Semakin tinggi intensitas komunikasi dan interaksi dalam keluarga akan berdampak pada semakin tinggi kesempatan untuk berbagi dan saling mendukung dan menciptakan kedekatan satu sama lain. Persoalannya, ketika wanita memilih untuk berkarir, maka waktu untuk melakukan komunikasi dan interaksi menjadi lebih terbatas. Jika hal ini terjadi dalam waktu yang lama, maka dapat berdampak pada kedekatan seorang istri dengan suami dan anaknya. Konflik keluarga dan pekerjaan (karir) sebentulnya bukan merupakan hambatan bagi istri karir, melainkan sebuah tantangan yang harus diatasi. Namun, konflik keluarga dan pekerjaan dapat 
memberikan pengaruh signifikan terhadap keberhasilan seorang istri dalam perannya sebagai ibu rumah tangga dan peran- nya dalam pekerjaan.

\section{Perempuan dalam Ekonomi Islam}

Sistem ekonomi Islam tentu saja melibatkan banyak unsur, antara lain; Negara, masyarakat beserta kebiasaannya dan peraturan. Jadi konstruksi ekonomi Islam bukan independen, khusus dalam bingkai ekonomi, namun terikat dan bersinggungan langsung dengan variabel lain. Maka sistem ekonomi Islam bersifat sistemik karena melibatkan banyak unsur yang membentuk dan mempengaruhi penerapan ekonomi Islam tersebut.

Al-Qur'an telah memberikan pandangan terhadap keberadaan dan kedudukan perempuan. Islam sangat memberikan kesempatan kepada perempuan untuk mengembangkan dirinya sebagai sumber daya manusia di tengah-tengah masyarakat dan telah secara jelas mengajarkan adanya persamaan antara manusia laki-laki dan perempuan maupun antar bangsa, suku dan keturunan. Islam dengan kitab suci alQur'an dan melalui Rasulullah SAW telah hadir secara ideal dengan gagasan besar mengajarkan prinsip dasar kemanusiaan, perlindungan hak asasi manusia dan kesederajatan serta mengajarkan setiap muslim untuk bekerja dan berusaha memakmurkan dunia, kebebasan mencari rizki sesuai dengan ketentuan dan norma syariat agama serta perintah mengerjakan amal shaleh yang bermanfaat bagi orang lain. Konsekuensi dari kewajiban ini adalah bahwa setiap manusia berhak untuk bekerja mendapatkan perkerjaan.

Adanya ungkapan bahwa wanita adalah tiang negara yang menunjukkan bahwa kedudukan perempuan sangatlah strategis dalam kehidupan bermasyarakat, berbangsa dan bernegara serta tidak ada perdebatan mendasar mengenai hal tersebut. Terlepas banyaknya kasus menyangkut perempuan, kita sudah sepatutnya untuk mengkonstruksi seideal mungkin dalam sudut pandang yang komprehensif.

Perempuan pekerja yang disamakan artinya dengan pekerja perempuan dapat memiliki makna sesuai dengan definisi pekerja seperti disebutkan diatas sebagai perempuan yang bekerja. Bekerja sesungguhnya merupakan perwujudan dari eksistensi dan aktualisasi diri manusia dalam hidupnya. Manusia, baik laki-laki 
maupun perempuan diciptakan Allah SWT untuk melakukan aktivitas pekerjaannya dan merupakan bagian dari amal shaleh. Selain dimaknai sebagai ibadah, dengan bekerja maka seseorang akan dapat memenuhi kebutuhan hidupnya, baik secara jasmani maupun rohani. Islam mengajarkan adanya kewajiban untuk bekerja sekaligus hak untuk mendapatkan pekerjaan yang dapat berlaku baik laki-laki maupun perempuan. Manusia dituntut untuk memperjuangkan kebutuhan hidup, seperti sandang, pangan, papan dan kesehatan.

Berdasarkan kitab Fiqih, Jamaluddin Muhammad Mahmud menyatakan bahwa perempuan dapat bertindak sebagai pembela dan penuntut dalam berbagai bidang. Dengan ilmu pengetahuan dan keterampilan yang dimiliki, perempuan mempunyai hak untuk bekerja dan menduduki jabatan tertinggi. Dalam pandangan

yang lain, bahwa Islam menempatkan laki-laki menjadi pemimpin dalam keluarga yang berkewajiban memberi nafkah, tetapi peran perempuan sebagai istri dan ibu bagi anak-anaknya untuk membantu ekonomi keluarga tidak bisa dihindari.

Bahkan di zaman modern sekarang ini, banyak menjadi wanita karir yang bekerja melebihi penghasilan suami. Secara kodrati, sesungguhnya perempuan mengemban tugas utama berkenaan dengan tugas-tugas reproduksi (hamil, melahirkan, menyusui, mengasuh anak) atau berkembang sebagai reproduktif (hamil, melahirkan, menyusui, pengasuhan, perawatan fisik dan mental untuk berfungsi dalam struktur masyarakat). Realitas bahwa perempuan bekerja disektor publik atau kerja produktif yang merupakan sebuah pilihan karena berbagai alasan. Di Arab Saudi misalnya, istri yang bekerja dan berkarir karena faktor ekonomi dan ingin mengimplementasikan ilmunya.

\section{Tinjauan Hukum Islam Terhadap Istri (Wanita Karir)}

Tujuan perkawinan yang begitu mulia, yaitu membina keluarga bahagia, kekal dan abadi berdasarkan Ketuhanan Yang Maha Esa, maka perlu diatur hak dan kewajiban serta kedudukan suami istri masing-masing. Apabila semua itu terpenuhi maka dambaan suami istri dalam bahtera rumah tangganya akan dapat terwujud, didasari rasa cinta dan kasih sayang. Kedudukan suami istri tersebut tidak terbatas dalam rumah tangga saja, tetapi juga dalam hubungannya dengan masyarakat yang 
Dede Hafirman: Peran Istri Dalam Membangun Ekonomi Keluarga |283

oleh pasal 31 Undang-Undang Nomor 1 tahun 1974 tentang Perkawinan. Hak dan kedudukan istri seimbang sama halnya dengan hak dan kedudukan suami dalam kehidupan rumah tangga, serta dalam pergaulan hidup bersama masyarakat.

Kewajiban suami terhadap istrinya diatur dalam Kompilasi Hukum Islam pasal 80, yaitu :

1) Suami adalah pembimbing terhadap istri dan rumah tangganya, akan tetapi tentang hal-hal urusan rumah tangga yang penting-penting diputuskan oleh suami istri bersama.

2) Suami wajib melindungi istrinya dan memberikan segala sesuatu keperluan hidup berumah tangga sesuai dengan kemampuannya.

3) Suami wajib melindungi istrinya dan memberikan segala sesuatu keperluan hidup berumah tangga sesuai dengan kemampuannya.

4) Suami wajib memberi pendidikan agama kepada istrinya dan memberi kesempatan belajar pengetahuan yang berguna dan bermanfaat bagi agama, dan bangsa.

5) Sesuai dengan penghasilannya suami menanggung; nafkah, kiswah dan tempat kediaman bagi istri, biaya rumah tangga, biaya perawatan dan biaya pengobatan bagi istri dan anak, biaya pendidikan bagi anak.

Bagi umat Islam di Indonesia, ketentuan tentang peranan istri dalam keluarga tersebut di atas ditegaskan kembali dalam Kompilasi Hukum Islam (KHI). Dengan redaksi yang berbeda, pasal 77 ayat pertama yang menyatakan bahwa suami istri memikul kewajiban luhur untuk menegakkan rumah tangga yang sakinah, mawaddah, dan rahmah yang menjadi sendi dasar dari susunan masyarakat. Dengan lebih rinci, ayat 3 (tiga) menegaskan bahwa suami istri memikul kewajiban untuk mengasuh dan memelihara anak-anak mereka, baik mengenai pertumbuhan jasmani, rohani, maupun kecerdasannya dan pendidikan agamanya. Demikian juga untuk urusan tempat tinggal di mana Kompilasi Hukum Islam ini mengadopsi secara verbatim ketentuan yang ada dalam Undang-undang Perkawinan, rumah kediaman yang dimaksud dalam ayat pertama ditentukan oleh suami istri secara bersama. ${ }^{20}$

Keluarga merupakan unit terkecil dalam masyarakat yang terdiri dari suami istridan anaknya. Meskipun keberadaan Keluarga merupakan bagian masyarakat 
terkecil, akan tetapi menjadi faktor terpenting dalam penentuan terwujudnya ketertiban dan ketentraman masyarakat. Allah menjadikan unit keluarga yang dibina dengan perkawinan antara suami istridalam membentuk ketenangan dan ketentraman serta mengembangkan cinta dan kasih sayang sesama warganya. ${ }^{21}$

Dengan demikian, kedudukan istri yang memilih untuk mempunyai pekerjaan di luar rumah, baik bekerja pada suatu tempat tertentu maupun yang menjalankan suatu kegiatan usaha pribadi istri tersebut, sesungguhnya mengharapkan keadaan ideal yaitu tetap dekat dengan anak dan keluarga, maksimal dapat mendampingi anak-anak dan suami. Idealnya istri tetap dapat menyalurkan kebutuhan untuk bersosialisasi sebagai makhluk sosial, mampu mandiri dari segi keuangan, dapat mengembangkan wawasan, serta perasaan bangga dan dihargai. Kondisi ideal yang diinginkan tersebut selain terkait lingkungan juga pribadi istri yang bekerja sudah mempersiapkan diri lahir dan bathin untuk tercapainya kondisi ideal tersebut.

Tujuan istri yang memilih pekerjaan di luar rumah untuk membantu meringankan beban suami adalah semata-mata untuk memenuhi kebutuhan keluarga tetapi juga tetap mengurus rumah tangga. Keadaan ini disebabkan karena penghasilan suami belum mencukupi kebutuhan hidup rumah tangga. Kondisi perekonomian yang lemah memaksa istri turut bekerja membantu suami dalam rangka mendapatkan penghasilan tambahan. Dengan kata lain keterlibatan istri bekerja di luar rumah terutama karena tuntutan ekonomi.

Jenis pekerjaan yang dapat menghilangkan sifat dasar kewanitaan seorang wanita, misalnya menjadi supir taksi siang dan malam, bekerja sebagai kuli konstruksi bangunan, bekerja berat di pabrik, bekerja sebagai pedagang yang bercampur baur antara laki-laki dan wanita, dan berbagai jenis pekerjaan lain yang secara zhahir identik dengan pekerjaan laki-laki. Selain itu, wanita tidak boleh bekerja di pub atau diskotik yang melayani kaum laki-laki sambil menyanyi atau menari, atau menjadi model produk tertentu yang menampakkan lekuk-lekuk tubuh untuk memikat para pembeli.

Jenis pekerjaan yang sesuai dengan sifat dasar dan kodrat kewanitaannya dalam pandangan Islam adalah bidang pengajaran, pengobatan, perawatan, serta 
perdagangan, misalnya menjadi guru atau dosen, perawat, dokter, psikiater, psikolog, polisi wanita.Konflik peran ganda demi membantu meningkatkan kesejahteraan keluarga dengan meningkatkan penghasilan suami demi terwujudnya ketahanan ekonomi keluarga selayaknya tidak perlu terjadi, karena merupakan kewajiban bersama antara suami dan istri. Terwujudnya kondisi ketahanan ekonomi keluarga dibuktikan dengan terpenuhinya kesejahteraan keluarga baik kebutuhan primer dan sekunder dalam kehidupan keluarga.

Hukum Islam telah memberikan perhatian tentang status dan keberadaan istri yang bekerja di luar rumah. Dalam tradisi fikih, setidaknya terdapat tiga hukum yang berhubungan dengan status istri karir ini, yaitu mubah, haram, dan wajib. Status hukum ini berhubungan dengan kondisi yang mengiringi istri karir tersebut. Istrikarir hukumnya mubah atau diperbolehkan jika memahami dan memenuhi syarat-syarat yang membolehkan atau karena keadaan memaksa. Namun, harus dipahami bahwa sebuah kebutuhan yang mendesak ini harus ditentukan dengan kadar yang sesuai sebagaimana sebuah kaidah. ${ }^{22}$ Akan tetapi, status hukum mubah ini bisa menjadi haram, jika pekerjaan yang dipilih tidak sesuai dengan ajaran Islam karena pada hakikatnya Istriharus bekerja dalam rumah untuk mengurus keluarga dan anakanaknya, sehingga Ahmad Zahra Al-Hasany melarang istri bekerja di luar rumah. ${ }^{23}$ Perempuan bekerja di luar rumah juga bisa menjadi wajib apabila tidak ada orang lain dalam keluarga yang dapat menafkahi termasuk apabila suaminya sakit dan tidak mampu lagi untuk bekerja.

Pandangan ulama terhadap istri bekerja di luar rumah dapat dilihat dari beberapa contoh berikut:

1) Pada zaman Rasulullah yang dhohir, ada istri yang bertugas membantu kelahiran, semacam dukun bayi atau bidan pada saat ini dan juga yang mengkhitan anak-anak istri. Jenis pekerjaan istri ini, dalam perkembangannya dapat dilihat pada pekerjaaan seorang dokter istri spesialis kandungan, seorang perawat, tenaga pengajar yang khusus mengajar istri dan yang sejenisnya.

2) Partisipasi kaum istri yang dilakukan istri Anshor pada waktu ikut Rosulullah berperang bersama Ummu Sulaim, yaitu dengan bekerja memberi minum, mengurus masalah pengobatan, menyediakan alat-alat dan mengobati para 
286 |AT-TAWASSUTH: Jurnal Ekonomi Islam, Volume V No. 2

Juli - Desember 2020: 268 - 290

prajurit yang terluka. ${ }^{24}$

3) Istri yang bekerja yang dapat dilihat dari yang dilakukan oleh Siti Khadijah dan Siti Aisyah sebagai istri karir yang berkecimpung dalam kegiatan profesi.

Dalam Islam meskipun ada perbedaan pendapat tentang diperbolehkan atau tidak istri bekerja di luar rumah, istri tidak boleh melalaikan kewajiban sebagai istriuntuk menciptakan keharmonisan yang penuh kasih sayang dalam rumah tangga. Husein Syahatah berpendapat bahwa istri dapat bekerja di luar rumah, jika memenuhi syarat dan syariat Islam serta bekerja sesuai dengan fitrahnya. Syarat-syarat tersebut, mulai dari izin suami, menyeimbangkan peran domestik dan peran publik, tidak terjadi khalwat, dan sesuai dengan karakter istri.

Syarat yang paling utama seorang istri bekerja di luar rumah adalah izin dari suami atau walinya karena adanya batasan pergaulan istri dengan yang bukan mahram. ${ }^{25}$ Maksud izin di sini adalah pemberitahuan istri kepada suami sebelum ia mulai bekerja. Namun demikian, izin suami tidak dapat diterjemahkan secara mutlak dan mengikat. Suami boleh melarang istrinya bekerja (dengan tidak memberi izin) jika pekerjaan yang akan dilakukan istri dapat membawa kemudharatan bagi dirinya dan keluarganya. Dalam kondisi seperti inilah suami berkewajiban untuk mengingatkannya bahkan melarang istrinya bekerja di luar rumah. Tetapi jika tujuan istri bekerja untuk mencari nafkah bagi keluarganya, akibat suami tidak mampu bekerja mencari nafkah, karena suami sakit atau miskin, maka suami tidak berhak melarangnya. $^{26}$

Demi membantu meningkatkan kesejahteraan keluarga dengan meningkatkan penghasilan suami demi terwujudnya ketahanan ekonomi keluarga selayaknya tidak perlu terjadi, karena merupakan kewajiban bersama antara suami dan istri. Terwujudnya kondisi ketahanan ekonomi keluarga dibuktikan dengan terpenuhinya kesejahteraan keluarga baik kebutuhan primer dan sekunder dalam kehidupan keluarga. Fakta memperlihatkan bahwa seorang istri yang bekerja di luar sebagai pencari nafkah ternyata tidak pernah meninggalkan tugas dan tanggungjawabnya. 
Peran pemerintah sangat penting untuk mendukung proses ketahanan ekonomi keluarga dalam memenuhi kebutuhan dasar. Dengan adanya regulasi yang lebih memperhatikan kebutuhan wanita yang bekerja di luar rumah dalam dunia kerja, diharapkan wanita dapat melaksanakan kewajiban sebagai istri dan melakukan pekerjaan di luar rumah dengan baik.

Kesejahteraan keluarga dapat terwujud dengan adanya sistemmanajemen yang baik, serta berjalannya fungsi dan perang masing-masing anggota keluarga. Hal ini menunjukkan bahwa antara peran suami sebagai kepala rumah tangga dan istri sebagai ibu rumah tangga harus berjalan dengan seiring sejalan. Suami sebagai kepala keluarga bertanggungjawab untuk mencari nafkah demi kesejahteraan keluarga. Di sisi lain sebagai ibu rumah tangga, istri harus mempunyai kreativitas dalam mengelola ekonomi keluarga.

\section{Kesimpulan}

Faktor yang menyebabkan istri untuk berkarir tidak hanya disebabkan oleh faktor ekonomi, melainkan juga faktor individu yang ditimbulkan oleh keinginan untuk mengembangkan diri dan berperan di dalam masyarakat. Namun, disisi lain, ketika seseorang istri terjun di dalam dunia karir, ia akan memiliki peran ganda, yaitu dalam rumah tangga dan pekerjaan (karir). Dalam banyak kasus, istri yang berkarir sering dihadapkan pada konflik keluarga dan pekerjaan. Keterlibatan wanita dalam mencari nafkah keluarga berpengaruh terhadap ketahanan ekonomi rumah tangga. Wanita yang bekerja di luar rumah rentan akan peran ganda yang harus diemban. Beberapa pengaruh negatif wanita yang bekerja di luar rumah yang lain juga timbul seperti kekurangan waktu bersama keluarga dan bermasyarakat yang berakibat pada potensi ada jarak kedekatan dengan anggota keluarga dan problem sosial yang lain. Untuk meminimalisir hal ini maka dapat dilakukan komunikasi yang baik pada suami dalam memenuhi tanggung jawab sebagai ibu rumah tangga. Konflik peran ganda wanita yang bekerja di luar rumah untuk ketahanan ekonomi keluarga dapat diselesaikan misalnya dengan izin suami, keseimbangan antara peran domestik dan publik, dari segi syariah, tidak menimbulkan khalwat dengan lawan jenis dan menjauhi pekerjaan yang tidak sesuai dengan fitrah kewanitaannya. 


\section{Endnote}

${ }^{1}$ Dalam Kamus Besar Bahasa Indonesia kata Istri berarti perempuan dewasa Departemen Pendidikan dan Kebudayaan, Kamus Besar Bahasa Indonesia, 4th edition (Jakarta: Gramedia Pustaka Utama, 2018), h. 372.

${ }^{2}$ Hafiz Anshary menyebut Istri yang bekerja di luar rumah dengan istilah Istri karir, istilah baru yang sering digunakan untuk menyebut Istri yang bekerja di luar rumah mencari nafkah, adalah Istri profesional. Ibid., h. 11

${ }^{3}$ Ayatullah Khomcini, Kedudukan Istri,(Jakarta: Pustaka Lentera, 2004), h.45

${ }^{4}$ Muhammad Thalib, Solusi Islami Terhadap Dilema Istri Karir, (Yogyakarta: Wihdah Press, 2003), h.15

${ }^{5}$ Muhammad Sobary, Menakar Harga Istri, Istri Dalam Budaya Dominasi Simbolis dan Actual Kaum Lelaki, (Bandung, Mirzan, 1999), h.8

${ }^{6}$ Gina and Anshori, Peran Istri Domestik dan Publik (Jakarta: Kencana, 1997), h. 201.

${ }^{7}$ Irwan Abdullah, Peran Gender (Yogyakarta: Pustaka Pelajar, 1997), h. 22

${ }^{8}$ Asmara, 'Peran Istri Bekerja dalam Meningkatkan Kesejahteraan Keluarga di Desa Muara Muntai Ilir Kecamatan Muara Muntai Kabupaten Kutai Kartanegara', Journal Sosiatri-Sosiologi, vol. 6, no. 1(2018).

${ }^{9}$ (QS. Ali Imran: 36)

${ }^{10}$ (QS. AN-Nisaa':1)

${ }^{11}$ Allah memudahkan bagi anak Adam pengangkutan-pengangkutan di daratan dan di lautan untuk memperoleh penghidupan.

${ }^{12}$ Departemen Agama RI, Al-Qur’an danTerjemahnya (Jakarta: PT.Syamil, 2005), h. 278

${ }^{13}$ Muhammad Sobary, Menakar Harga Istri, Istri Dalam Budaya Dominasi Simbolis dan Actual Kaum Lelaki, (Bandung: Mizan, 1999), h. 83

${ }^{14}$ Departemen Agama RI, Al-Qur’an danTerjemahan (Jakarta: PT.Syamil, 2005), h. 17

${ }^{15}$ Wawancara, ibu Dini pada tanggal 1 September 2020.

${ }^{16}$ Wawancara, ibu Isra pada tanggal 2 September 2020

${ }^{17}$ Wawancara, ibu reni pada tanggal 3 September 2020

${ }^{18}$ Wawancara ibu Intan pada tanggal 3 September 2020

${ }^{19}$ wawancara, ibu rizka ar- rahmah pada tanggal 3 September 2020 
Dede Hafirman: Peran Istri Dalam Membangun Ekonomi Keluarga | 289

20

Undang-Undang Republik Indonesia Nomor 1 Tahun 1975 Tentang Perkawinan dan Kompilasi Hukum Islam (Jakarta: Grahamedia Press, 2014), hlm. 355

${ }^{21}$ Abdul Rahman Ghozali, Fiqh Munakahat (Jakarta: Kencana, 2003), hlm. 22-31

${ }^{22}$ Abu Muhammad Asraf, Curhat Pernikahan (Bandung: Pustaka Rahmat, 2009), hlm. 93.

23 M. Hasan Ali, Masail Fiqhiyah Al-Haditsah pada Masalah-Masalah Kontemporer Hukum Islam (Jakarta: PT Raja Grafindo Persada, 1998), hlm. 193.

24 Ibrahim Amini, Bimbingan Islam untuk Kehidupan Suami Istri (Bandung, 1998), hlm. 114.

25 Muhammad Restu Sugiharto, The Inner Power of Muslimah (Jakarta: Mizan Publika, 2008), h. 117

${ }^{26}$ Abû Zakariyyâ Yahyâ bin Syaraf al-Nawawî, Raudhah al-Thâlibîn, vol. IV, hlm. 485.

\section{Daftar Pustaka}

Abdullah, Irwan. 2007. Peran Gender. Yogyakarta: Pustaka Pelajar.

Ali, M. Hasan. 1998. Masail Fiqhiyah Al-Haditsah pada Masalah-Masalah Kontemporer Hukum Islam. Jakarta: PT Raja Grafindo Persada.

Amini, Ibrahim. 1998. Bimbingan Islam untuk Kehidupan Suami Istri . Bandung: AlBayan.

Asmara. 2018. Peran Istri Bekerja dalam Meningkatkan Kesejahteraan Keluarga di Desa Muara Muntai Ilir Kecamatan Muara Muntai Kabupaten Kutai Kartanegara, Journal Sosiatri-Sosiologi, Vol. 6, No. 1.

Asraf, Abu Muhammad. 2009. Curhat Pernikahan. Bandung: Pustaka Rahmat.

Departemen Agama RI. 2005. Al-Qur'an danTerjemahnya Jakarta: PT.Syamil.

Departemen Pendidikan dan Kebudayaan. 2018. Kamus Besar Bahasa Indonesia, 4th edition. Jakarta: Gramedia Pustaka Utama.

Ghozali, Abdul Rahman. 2003. Fiqh Munakahat. Jakarta: Kencana.

Gina dan Anshori. 1997. Peran Istri Domestik dan Publik Jakarta: Kencana.

Khomcini, Ayatullah. 2004. Kedudukan Istri. Jakarta: Pustaka Lentera. 
290 AT-TAWASSUTH: Jurnal Ekonomi Islam, Volume V No. 2

Juli - Desember 2020: 268 - 290

al-Nawawî, Abû Zakariyyâ Yahyâ bin Syaraf. 2003. Raudhah al-Thâlibîn, Vol. IV.

Sobary, Muhammad. 1997. Menakar Harga Istri, Istri Dalam Budaya Dominasi Simbolis dan Actual Kaum Lelaki. Bandung: Mizan.

Sobary, Muhammad. 1999. Menakar Harga Istri, Istri Dalam Budaya Dominasi Simbolis dan Actual Kaum Lelaki. Bandung: Mirzan.

Sugiharto, Muhammad Restu. 2008. The Inner Power of Muslimah. Jakarta: Mizan Publika..

Thalib, Muhammad. 2003. Solusi Islami Terhadap Dilema Istri Karir. Yogyakarta: Wihdah Press.

Undang-Undang Republik Indonesia Nomor 1 Tahun 1975 Tentang Perkawinan dan Kompilasi Hukum Islam. Jakarta: Grahamedia Press. 